\title{
Studi Analisis Perilaku Jembatan Pejalan Kaki dengan Sambungan Sekrup dan Adhesive pada Cold-Formed Steel
}

\author{
Richo Oktavian Indarto ${ }^{1, *}$, Budi Suswanto ${ }^{1}$ \\ Departemen Teknik Sipil, Institut Teknologi Sepuluh Nopember, Surabaya ${ }^{1}$ \\ Koresponden*, Email: oktavian_richo@yahoo.co.id
}

\begin{tabular}{|c|c|c|}
\hline & Artikel & Abstract \\
\hline Diajukan & 1 Agustus 2019 & Pedestrian Bridge is currently built in the city center of Indonesia. Generally, Pedestrian \\
\hline Diper & 5 Agust & cting one to the other building and serve crossing bridge for the \\
\hline Dis & 5 Agustus 2019 & $\begin{array}{l}\text { traffic. Therefore, design of the bridge must be considered of the function. Steel frame bridge } \\
\text { (Hot Rolled) is one of the type bridge materials that used in Indonesia because the structure, } \\
\text { the availability materials and the easy installation. Mild steel frame structure is one of the } \\
\text { materials which used in the construction of pedestrian bridge. Its connected with plates, screws } \\
\text { or adhesive. This research analyzed mild steel frame structure connected with screws and } \\
\text { adhesive. Modeling of the pedestrian bridge used } 4800 \times 750 \times 1200 \text { mm. Comparation of the }\end{array}$ \\
\hline $\begin{array}{l}\text { Keywords } \\
\text { steel, } \text { mod }\end{array}$ & dge, cold formed & $\begin{array}{l}\text { analysis used auxiliary program } A B A Q U S \text { and } S A P 2000 \text {. The result of the analysis by } \\
\text { ABAQUS is able to hold the force into } 1003,69 \mathrm{~kg} \text { and } 1312,96 \mathrm{~kg} \text {. }\end{array}$ \\
\hline
\end{tabular}

\begin{abstract}
Abstrak
Jembatan Pejalan Kaki saat ini mulai banyak dibangun di Indonesia. Pada umumnya jembatan dibangun sebagai sarana penghubung dari satu bangunan ke bangunan lainnya dan berfungsi sebagai jembatan penyeberangan lalu lintas. Dalam perancangan jembatan sebaiknya mempertimbangkan fungsi kebutuhan transportasi, persyaratan teknis, beban dinamis dan estetika arsitektural. Jembatan rangka baja (Hot Rolled) merupakan salah satu bahan jembatan yang banyak digunakan di Indonesia karena bentuk strukturnya, ketersediaan material dan kemudahan pemasangannya di lapangan. Struktur rangka baja ringan merupakan salah satu pilihan material yang digunakan dalam membuat konstruksi jembatan pejalan kaki dengan penyambungan pelat, sekrup, maupun adhesive. Penelitian ini menganalisa struktur rangka baja ringan menggunakan sambungan sekrup dan adhesive. Pemodelannya menggunakan ukuran jembatan pejalan kaki sebesar $4800 \mathrm{~mm} x$ $750 \mathrm{~mm} \times 1200 \mathrm{~mm}$. Perbandingan analisis dengan program bantu SAP2000 dan ABAQUS. Hasil analisis dengan ABAQUS mampu menahan gaya sampai 1003,69 kg dan 1312,96 kg.
\end{abstract}

\section{Pendahuluan}

Jembatan merupakan bagian dari jalan (penghubung) yang diperlukan dalam sistem jaringan transportasi yang nantinya akan menunjang pembangunan pada suatu daerah. Berikut data perkembangan pembangunan jembatan di Indonesia yang terangkum pada Tabel 1.

Dalam perancangan jembatan sebaiknya mempertimbangkan fungsi kebutuhan transportasi, persyaratan teknis dan estetika arsitektural yang meliputi: aspek lalu lintas, aspek teknis dan aspek estetika[1].

Jembatan rangka baja (Hot Rolled) salah satu tipe perancangan jembatan yang digunakan di Indonesia karena bahan materialnya tersedia dan mudah pemasangannya di lapangan. Baja ringan memiliki berat jenis yang relatif ringan sehingga mudah untuk dibawa ke suatu tempat, dalam penggunaannya cukup cepat dan efisien secara waktu.

Tabel 1. Perkembangan Jumlah Pembangunan Jembatan di Indonesia

\begin{tabular}{lccccc}
\hline No. & Bentang & \multicolumn{2}{c}{ Panjang } & \multicolumn{2}{c}{ Jumlah } \\
& $(\mathrm{m})$ & $\mathrm{km}$ & $\%$ & Buah & $\%$ \\
\hline 1 & $0-20$ & 93,9 & 30 & 12,068 & 73 \\
2 & $20-40$ & 42,6 & 13 & 1,849 & 11 \\
3 & $40-60$ & 68,6 & 22 & 1,741 & 10 \\
4 & $60-100$ & 39,3 & 12 & 544 & 3 \\
5 & $>100$ & 71,8 & 23 & 385 & 2 \\
& & 316,2 & 100 & 16,587 & 100 \\
\hline
\end{tabular}

Sumber: Direktorat Bina Teknik, Jenderal Bina Marga, Departemen Pekerjaan Umum 2007 [2]

Jembatan rangka baja (Hot Rolled) salah satu tipe perancangan jembatan yang digunakan di Indonesia karena bahan materialnya tersedia dan mudah pemasangannya di lapangan. Baja ringan memiliki berat jenis yang relatif ringan sehingga mudah untuk dibawa ke suatu tempat, dalam penggunaannya cukup cepat dan efisien secara waktu. 
Ketika rangka baja ringan menahan beban yang bekerja, pada bagian sambungan merupakan daerah yang paling rawan mengalami kegagalan terlebih dulu[3]. Penelitian sebelumnya sudah mempelajari tentang perkuatan pada sambungan yang dapat memberikan kontribusi pada struktur. Kontribusi pada struktur yaitu mengurangi lendutan sebesar $10,5 \%$ dan meningkatkan kemampuan menahan beban sebesar $15 \%$ [3]. Bentuk rangka jembatan baja ringan untuk pejalan kaki yang hanya menganalisis pada rasio berat dan lendutan pernah dilakukan oleh[4].

Sambungan merupakan suatu material yang digunakan untuk menyambung profil satu dengan profil lainya pada suatu rangka material. Umumnya alat sambung yang digunakan adalah baut, sekrup, las, adhesive dan keling. Sambungan struktur baja ringan dengan menggunakan adhesive dapat meningkatkan kapasitas struktur yang signifikan menurut[5].

Pada penelitian sebelumnya [6] meneliti tentang beban kelompok meloncat dengan menggunakan analisis numerikal. Analisis ini didasarkan atas hasil eksperimen dari 64 orang yang meloncat secara kelompok dan individu. Figueiredo [7] mengembangkan model pembebanan yang akan mempengaruhi beban di JPO. Dilakukan studi dari beberapa jembatan penyeberangan orang dengan tipe komposit dengan panjang jembatan antara 10-35 meter.

Pada penelitian ini akan mencoba menggunakan sambungan sekrup dan adhesive sebagai salah alternatif rancang jembatan untuk pejalan kaki dengan cold-formed steel. Hasil penelitian diharapkan dapat memberikan rancang rangka struktur baja ringan dalam konstruksi jembatan pejalan kaki.

\section{Metode}

Penelitian ini menggunakan studi literatur sebagai acuan, studi literatur dilakukan untuk mengetahui lebih jauh tentang pengaruh beban dinamis manusia terhadap struktur jembatan baja ringan seperti transfer gaya-gaya dalam yang bekerja pada hubungan sistem sambungan, model kegagalan sambungan sekrup dan adhesive, perilaku sambungan pada struktur jembatan baja ringan. Hasil dari studi literatur dapat dijadikan sebagai acuan terhadap detail permasalahan penelitian yang akan dibahas, terutama analisis kegagalan struktur pada sambungan sekrup dan adhesive. Hasil dari analisis berupa gaya dan perpindahan yang sesuai dengan ketentuan[8], kemudian diverifikasi dengan menggunakan program bantu ABAQUS.

Preliminary design yang dilakukan mencakup pada perencanaan dimensi struktur, perencanaan model tipe jembatan, dan perencanaan sambungan kombinasi sekrup dan adhesive hingga pada kontrol kapasitas sambungan.
Adhesive adalah bahan yang digunakan untuk menahan setidaknya dua permukaan secara bersama-sama dengan kuat dan permanen. Sifat yang harus dimiliki bahan adhesive adalah harus mampu membasahi seluruh permukaan, mampu melekat pada permukaan, dan mampu menahan beban ketika diberi suatu gaya. Bahan baku untuk perekat biasanya terbuat dari polimer, baik polimer alam maupun sintetis[9].

Try and error pada pemodelan dibuat guna untuk mengetahui desain yang paling efektif, ringan, dan yang paling mudah untuk diterapkan dalam eksperimental atau membuat benda uji.

Data spesifikasi desain jembatan sebagai berikut:

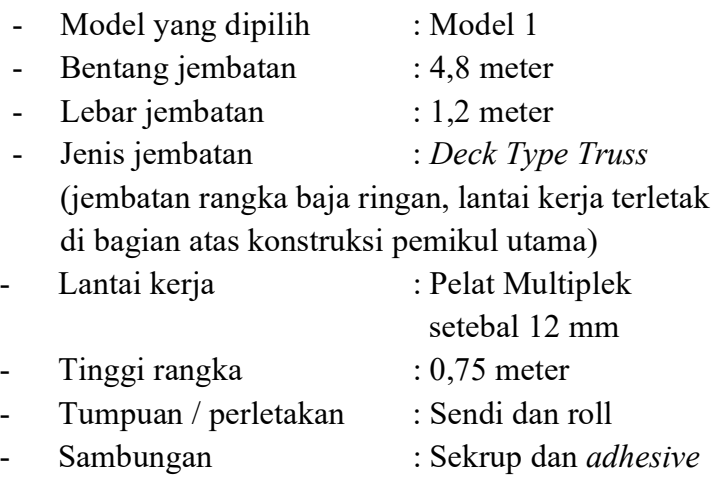

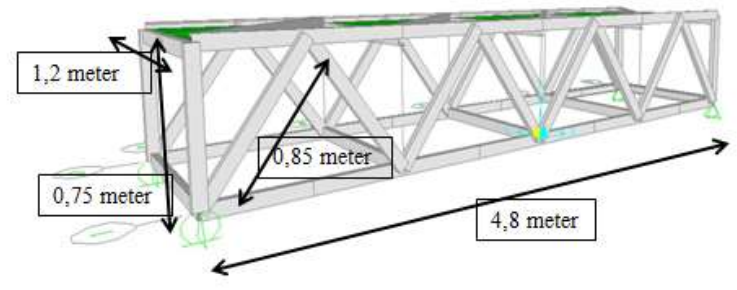

Gambar 1. Desain Model Struktur Jembatan Sumber: Hasil Analisis

\section{Hasil dan Pembahasan}

Pemodelan yang digunakan pada analisa penelitian ini adalan SAP2000 V.14.2.2 secara 3D dari data pengujian tarik baja ringan yang telah dilaksanakan oleh Sumaidi, Komara dan Santoso [10-12] dengan data spesifikasi dan dimensi baja ringan diambil sesuai data eksperimental.

Program bantu SAP2000 membantu dalam menganalisis nilai-nilai pembebanan dan kombinasi pembebanan yang kemudian muncul nilai gaya-gaya yang terjadi pada struktur jembatan pejalan kaki.

Setelah menghitung besar gaya yang terjadi, cek kapasitas yang dimulai dari cek kapasitas geser dan tarik kemudian cek kontrol lendutan yang terjadi pada struktur jembatan pejalan kaki yang awal desain menggunakan beban sebesar $1860 \mathrm{~kg}$ dan $1800 \mathrm{~kg}$ dari data eksperimental [12]. Dari SAP2000 bisa diketahui besaran lendutan yang terjadi. 


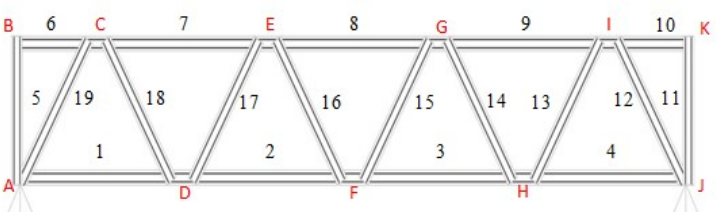

Gambar 2. Penomoran Rangka Utama Jembatan Pejalan Kaki

Sumber: Hasil Analisis

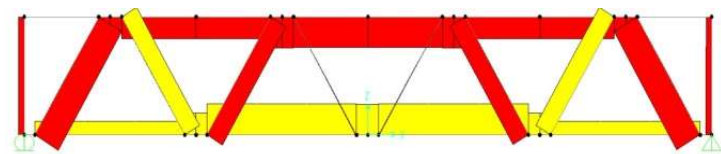

Gambar 3. Gaya Aksial pada Rangka Utama Jembatan Pejalan Kaki

Sumber: Hasil Analisis

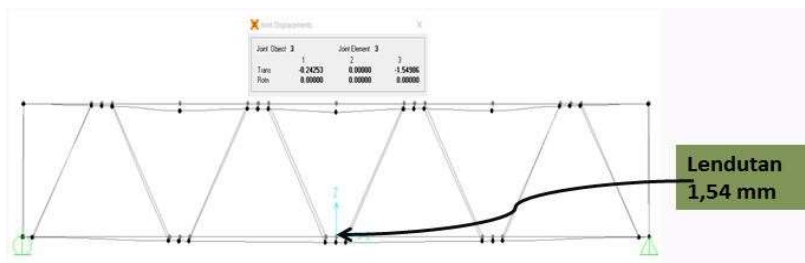

Gambar 4. Lendutan pada Jembatan Pejalan Kaki Beban $1860 \mathrm{~kg}$.

Sumber: Hasil Analisis

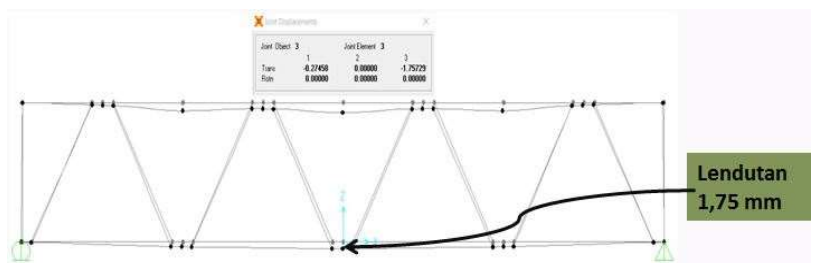

Gambar 5. Lendutan pada Jembatan Pejalan Kaki Beban $1800 \mathrm{~kg}$.

Sumber: Hasil Analisis

Dari gambar diatas jembatan pejalan kaki terjadi lendutan sebesar $1,75 \mathrm{~mm}$. Sedangkan standar maksimum lendutan yang diperbolehkan terjadi sebesar $5 \mathrm{~mm}$. Maka lendutan sebesar 1,75 mm dan 1,54 $\mathrm{mm}<5 \mathrm{~mm}$ (lendutan ijin) jadi bisa katakan bahwa jembatan pejalan kaki layak secara lendutan yang diijinkan telah memenuhi.

\section{Metode Finite Element}

Pemodelan dengan metode Finite Element bisa dilakukan dengan program bantu ABAQUS dengan bentuk shell 3D. Bentuk part berupa shell dengan material baja ringan.

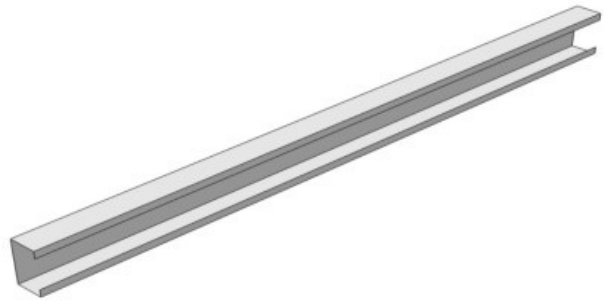

Gambar 6. Typikal Batang Baja Ringan pada ABAQUS Sumber: Hasil Analisis

Setelah pembuatan part untuk baja ringan, maka tahap selanjutnya sebelum dilakukan tahap pembebanan terlebih dahulu Assembly.

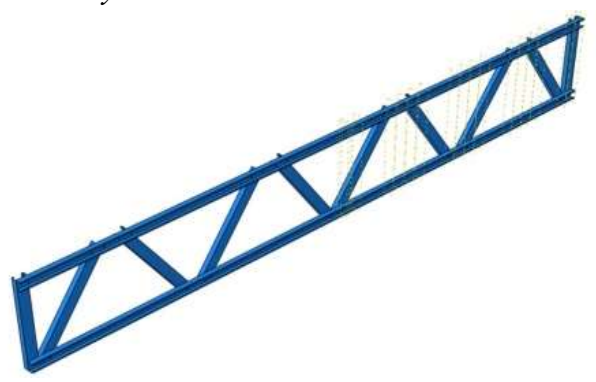

Gambar 7. Assembly Bentang Struktur dari Jembatan Pejalan Kaki

Sumber: Hasil Analisis

Setelah membuat model step sebagai asumsi awal menentukan jenis pembebanan yang digunakan pada program Abaqus. Penentuan jenis tumpuan pada model atau disebut boundary condition.

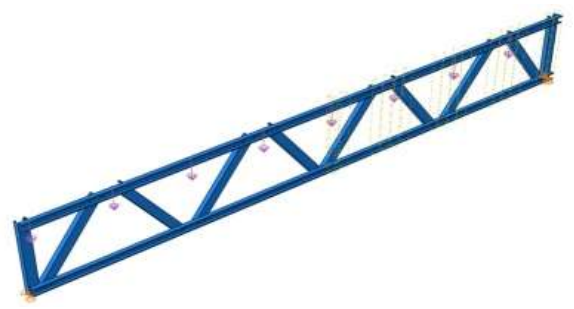

Gambar 8. Perletakan Boundary Condition pada Model Sumber: Hasil Analisis

Interaksi pada pemodelan ini tidak dilakukan satu per satu antar sambungan melainkan dibuat solid atau satu kesatuan untuk semua sambungan pada pemodelan. Dikarenakan ketika dibuat tidak solid pada proses running program bantu ABAQUS yang mengutamakan proses elemen hingga akan mengalami aborted atau gagal running. 


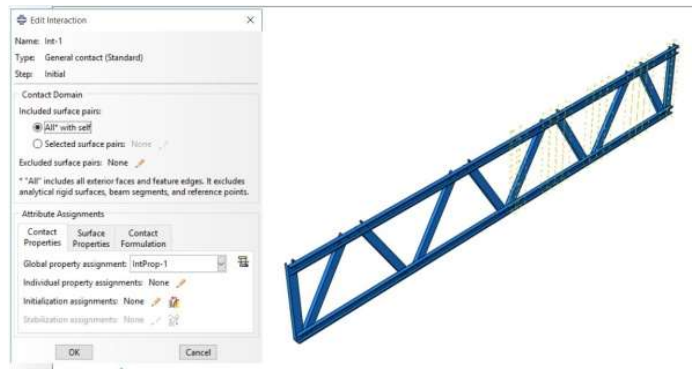

Gambar 9. Interaksi Secara Keseluruhan pada Batang Sumber: Hasil Analisis

Tahap selanjutnya setelah pemilihan interaksi maka memilih modul mesh.

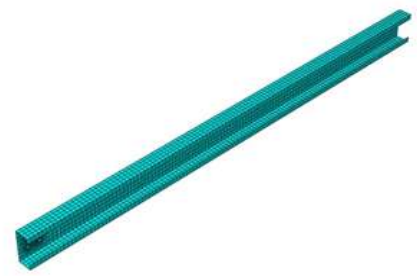

Gambar 10. Assembly dalam Bentuk Mesh. Sumber: Hasil Analisis

Tahap terakhir yaitu menganalisis pemodelan agar menjadi sebuah hasil analisa numerik atau angka. Proses Job memiliki beberapa langkah yaitu dari data check hingga menjadi sebuah results. Namun akan ada memberitahuan apabila proses data check ataupun proses submit berupa hasil completed atau aborted.

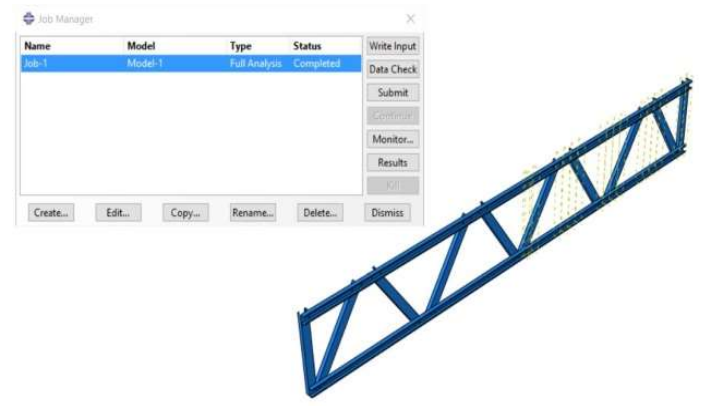

Gambar 11. Modul Job pada Program ABAQUS Melihat Nilai $S$ Mises dan U Magnitude

Sumber: Hasil Analisis

Ketika akan memulai menu Job perlu memilih menu Data Check terlebih dahulu guna mengecek secara keseluruhan pemodelan yang akan di running/submit.

Setelah proses running/submit berhasil maka dengan mudah bisa melihat hasil nilai $S$ Mises dari analisis struktur rangka jembatan.

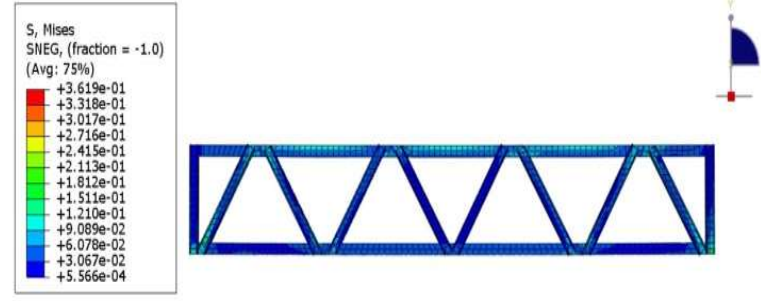

Gambar 12. Hasil S Mises pada Struktur Rangka Jembatan Sumber: Hasil Analisis

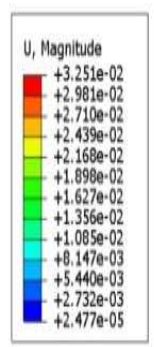

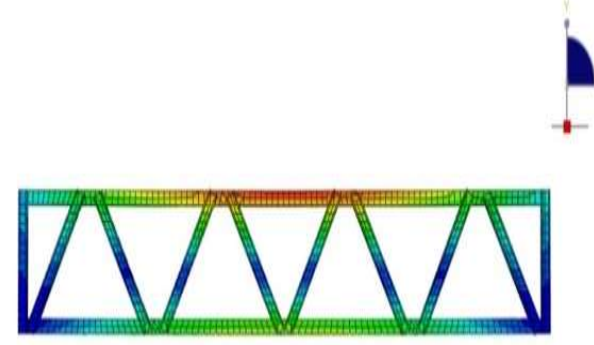

Gambar 13. Hasil U Magnitude pada Struktur Rangka Jembatan

Sumber: Hasil Analisis

Dari gambar diatas terdapat nilai sebesar 2,19 mm yaitu nilai lendutan yang terjadi pada struktur rangka jembatan pejalan kaki. Setelah diberi pembebanan secara menyeluruh pada posisi batang atas horisontal secara menyeluruh. Hasil dari nilai $U$ Magnitude ini akan digunakan sebagai acuan perbandingan antara hasil eksperimental, hasil analisis dengan program bantu SAP2000 dan program bantu ABAQUS. Cek titik node pada struktur rangka yaitu pada node tengah bawah bentang karena lendutan terbesar terjadi pada posisi tersebut.

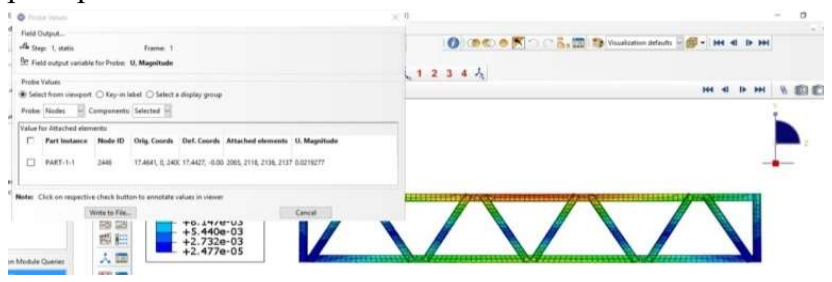

Gambar 14. Lendutan pada Titik Node Struktur Rangka Jembatan

Sumber: Hasil Analisis

\section{Definisi Material dan Assembly}

Pada sambungan huruf B antara batang nomor 5 dan 6 yang akan dianalisis untuk mengetahui seberapa besar kekuatan sambungan. Material baja ringan, sekrup dan adhesive didefinisikan pada program ABAQUS. Ada beberapa step material yang harus di isi untuk membuat 
definisi material diantara lain density, elastic dan plastic. Parameter material yang digunakan ada pada Tabel 2.

Tabel 2. Data Teknis Material CFS, Screw dan Adhesive

\begin{tabular}{|c|c|}
\hline \multicolumn{2}{|c|}{ Cold-Formed Steel } \\
\hline Density & \\
\hline Mass Density (kg/m3) & 7850 \\
\hline \multicolumn{2}{|l|}{ Elastic } \\
\hline Young's Modulus (MPa) & 200000 \\
\hline Poisson's Ratio & 0.3 \\
\hline \multicolumn{2}{|l|}{ Plastic } \\
\hline Yield Stress (MPa) & $643.85 ; 720$ \\
\hline Plastic Strain (MPa) & $0 ; 0.0658$ \\
\hline \multicolumn{2}{|c|}{ Screw } \\
\hline \multicolumn{2}{|l|}{ Density } \\
\hline Mass Density ( $\mathrm{kg} / \mathrm{m} 3)$ & 7850 \\
\hline \multicolumn{2}{|l|}{ Elastic } \\
\hline Young's Modulus (MPa) & 200000 \\
\hline Poisson's Ratio & 0.3 \\
\hline \multicolumn{2}{|l|}{ Plastic } \\
\hline Yield Stress (MPa) & $500 ; 550$ \\
\hline Plastic Strain (MPa) & $0 ; 0.0025$ \\
\hline \multicolumn{2}{|c|}{ Adhesive } \\
\hline \multicolumn{2}{|l|}{ Density } \\
\hline Mass Density (kg/m3) & 1950 \\
\hline \multicolumn{2}{|l|}{ Elastic } \\
\hline Young's Modulus (MPa) & 5000 \\
\hline Poisson's Ratio & 0.28 \\
\hline \multicolumn{2}{|l|}{ Plastic } \\
\hline Yield Stress $(\mathrm{MPa})$ & 22.7 \\
\hline Plastic Strain (MPa) & 0 \\
\hline
\end{tabular}

Proses Assembly ini dilakukan untuk membuat pemodelan sesuai dengan desain yang sudah dibuat, yaitu berupa penggabungan antara batang vertikal dan horisontal dengan penyambungan menggunakan sekrup dan adhesive.

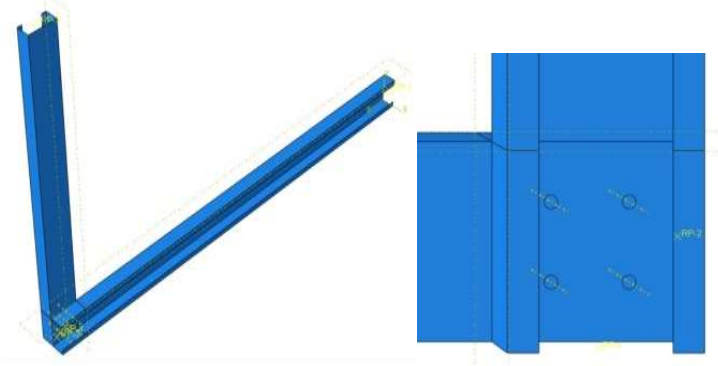

Gambar 15. Assembly Sambungan Baja Ringan dengan Sekrup

Sumber: Hasil Analisis

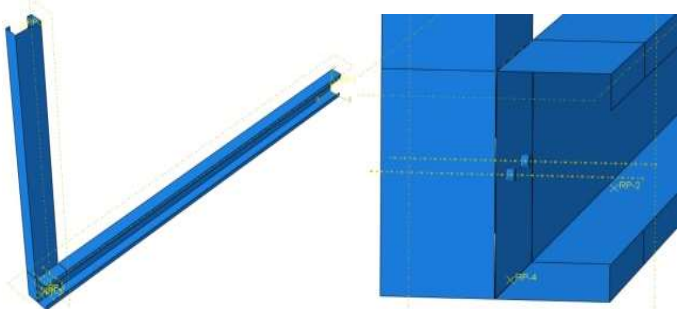

Gambar 16. Assembly Sambungan Baja Ringan dengan Sekrup dan Adhesive.

Sumber: Hasil Analisis

Tahap akhir dari analisis elemen hingga dengan program bantu ABAQUS yaitu menunjukkan perilaku yang terjadi antara baja ringan dan sekrup serta adhesive.

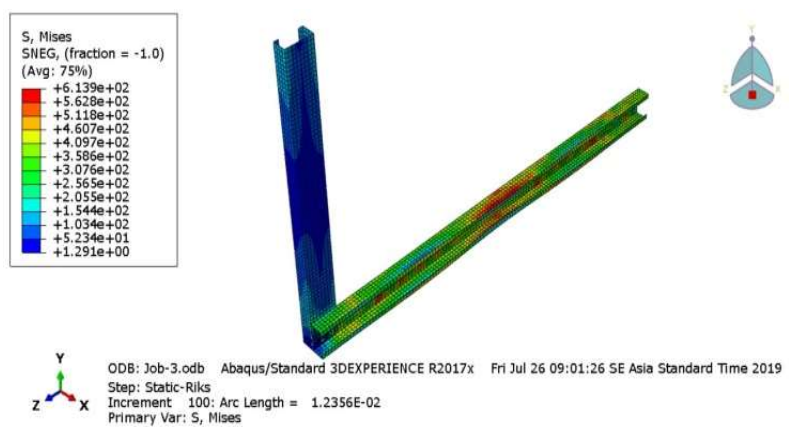

Gambar 17. Hasil S Mises Step 100 Model Sambungan Baja Ringan dengan Sekrup

Sumber: Hasil Analisis

Pada analisis jenis sambungan sekrup ketika step 100 menghasilkan perilaku lebih besar pada batang horisontal sedangkan pada batang vertikal hanya pada bagian ujungnya saja.
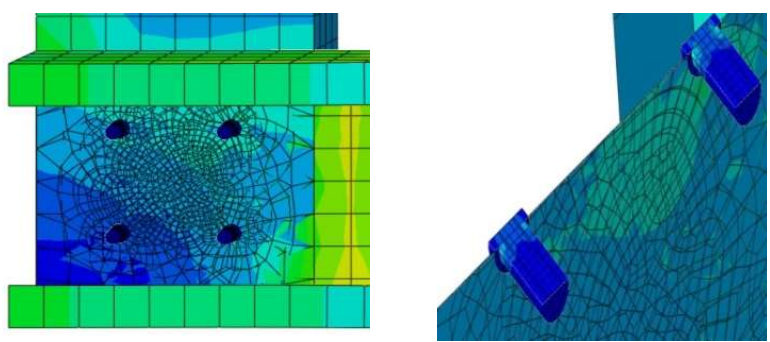

Gambar 18. Detail Hasil S Mises Step 100 dan Contour Specify Sekrup

Sumber: Hasil Analisis

Berikut penyajian detail hasil analisis jenis sambungan sekrup saja dengan jumlah sekrup 4 buah, mengalami perilaku hanya pada ujung/kepala sekrup. 


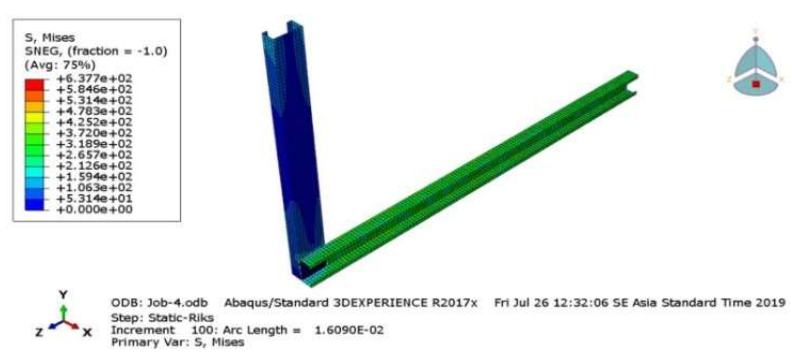

Gambar 19. Hasil S Mises Step 100 Model Sambungan Baja Ringan Dengan Sekrup dan Adhesive.

Sumber: Hasil Analisis

Sedangkan pada jenis sambungan sekrup dan adhesive juga mengalami perilaku pada batang horisontal namun tidak sebesar pada jenis sambungan yang menggunakan sekrup saja.
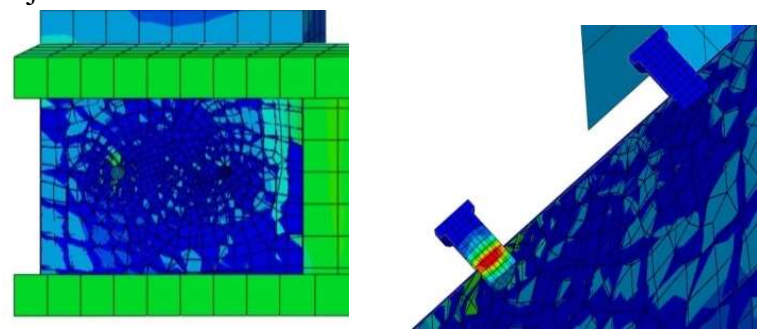

Gambar 20. Detail Hasil S Mises Step 100 dan Contour Specify Sekrup + Adhesive

Sumber: Hasil Analisis

Detail pada analisis sambungan sekrup dan adhesive terdapat kerusakan terutama pada perilaku badan sekrup yang lebih dahulu mengalami kerusakan/patah.

Pemodelan yang sudah dilakukan diatas yaitu berupa 2 jenis sambungan antara sambungan baja ringan dengan sekrup (CFS-S) dan sambungan baja ringan dengan sekrup dan adhesive (CFS-S $+\mathrm{A})$. Hasil dari 2 sambungan diatas menghasilkan gaya (force) dan perpindahan (displacement) seperti gambar di bawah ini.

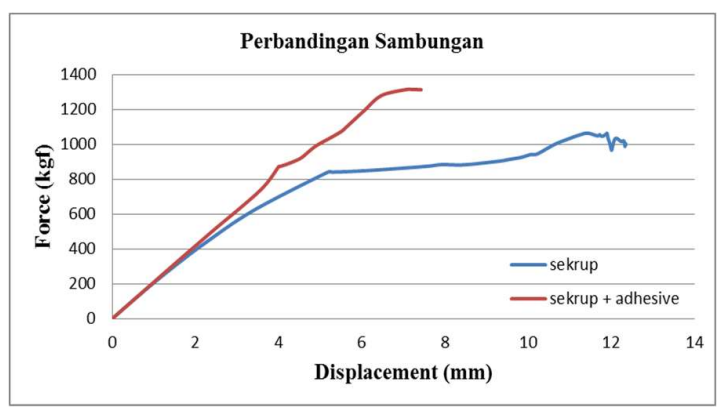

Gambar 21. Grafik Pertandingan Sambungan Baja Ringan Dengan Sekrup (CFS-S) dan Sambungan Baja Ringan Dengan Sekrup + Adhesive (CFS-S-A)

Sumber: Hasil Analisis
Dari Gambar 21 diatas dapat diambil garis besar kesimpulan bahwa jenis sambungan sekrup+adhesive mengalami perkakuan lebih besar daripada sambungan sekrup. Meskipun dengan mengurangi jumlah sekrup sebesar $50 \%$ dari jumlah sambungan sekrup saja, sambungan sekrup+adhesive lebih kaku dan daktail.

Setelah dilakukan perbandingan sambungan baja ringan antara sekrup dan sekrup + adhesive, maka selanjutnya ditinjau untuk perbandingan antara studi eksperimental sebelumnya yang telah dilakukan walaupun ada perbedaan pada pemodelan yang sebelumnya berupa plat baja ringan dan rangka atap. Setelah diplotkan 2 grafik perbandingan antara studi eksperimental dan studi analisis sehingga dapat ditarik perbedaan persentase berupa penurunan atau penaikan.

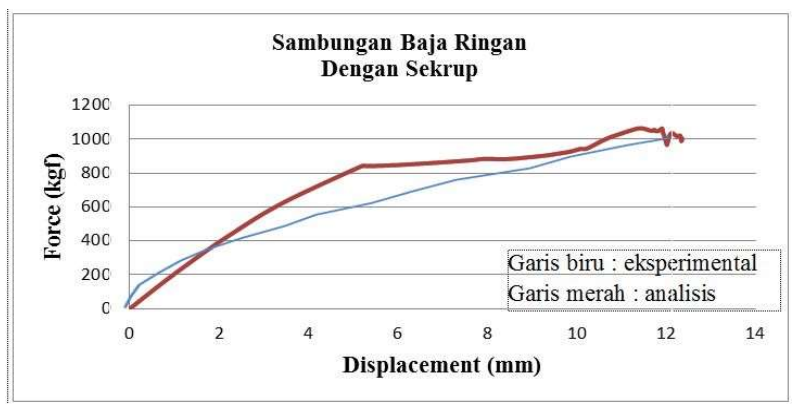

Gambar 22. Grafik Perbandingan Sambungan Baja Ringan dengan Sekrup (CFS-S) Antara Eksperimental dan Analisis Sumber: Hasil Analisis

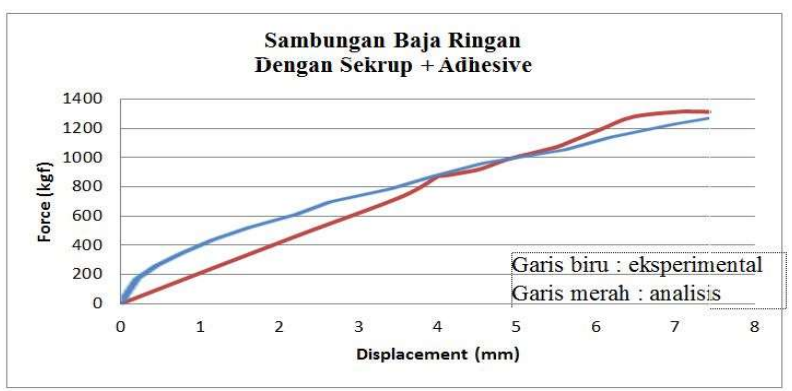

Gambar 23. Grafik Perbandingan Sambungan Baja Ringan dengan Sekrup + Adhesive (CFS-S $+\mathrm{A}$ ) Antara Eksperimental dan Analisis

Sumber: Hasil Analisis

Pada Gambar 22 dan 23 terdapat selisih dikarenakan perbedaan uji eksperimental dan analisis yaitu pada parameter sekrup yang digunakan dikarenakan pada pemodelan sekrup tidak bisa dibuat secara ril berupa sekrup drilling. Pada sambungan baja ringan dengan sekrup terjadi selisih prosentase sebesar $16,35 \%$ yang termasuk dalam kategori penurunan force dan displacement. Sebaliknya pada sambungan baja ringan dengan sekrup + adhesive terdapat 
selisih prosentase hanya sebesar $6,21 \%$ yang pada gambar grafik dalam kategori penaikan/kenaikan elastis. Secara garis besar grafik sambungan keduanya dari studi analisis terjadi perilaku plastis, yang dimana nilai plastis yang didapat pada sambungan sekrup + adhesive lebih panjang. Jadi kombinasi sambungan sekrup + adhesive dapat dijadikan alternatif sambungan yang dapat meningkatkan kemampuan plastis pada sambungan baja ringan.

\section{Simpulan}

Dari analisis diatas dapat disimpulkan bahwa:

1. Hasil perilaku yang terjadi pada struktur rangka jembatan pejalan kaki dengan program bantu ABAQUS tidak mengalami kondisi leleh pada elemen baja ringan. Karena elemen baja ringan mengalami tekuk terlebih dahulu setelah diberi pembebanan secara menyeluruh.

2. Lendutan yang terjadi dari SAP2000 sebesar $1,75 \mathrm{~mm}$ sedangkan pada ABAQUS 6.17 sebesar 2,19 mm. Apabila dideskripsikan yaitu kerusakan terjadi pada sisi struktur batang atas jembatan pejalan kaki karena penampang horisontal yang terlebih dahulu terkena beban dari atas. Sedangkan struktur batang lainnya menerima penyaluran beban dari atas penampang utama.

3. Hasil perbandingan sambungan baja ringan dengan sekrup menunjukkan perilaku dapat menahan gaya sampai 1003,69 kg sedangkan pada sambungan baja ringan dengan sekrup + adhesive yang hanya sebesar $1312,96 \mathrm{~kg}$. Namun pada kedua sambungan ini terdapat perbedaan perilaku yang dimana sambungan sekrup + adhesive lebih kaku sehinga sambungan lebih besar menerima gaya atau beban yang diterima. Perbandingan hasil eksperimental dan analisis sambungan baja ringan terdapat selisih dikarenakan perbedaan uji eksperimental dan analisis yaitu pada parameter sekrup yang digunakan dikarenakan pada pemodelan sekrup tidak bisa dibuat secara ril berupa sekrup drilling. Terjadi selisih prosentase sebesar $16,35 \%$ yang termasuk dalam kategori penurunan force dan displacement. Sebaliknya pada sambungan baja ringan dengan sekrup + adhesive terdapat selisih prosentase hanya sebesar $6,21 \%$ yang pada gambar grafik dalam kategori penaikan/kenaikan elastis.

\section{Daftar Pustaka}

[1] B. Supriyadi and A. S. Muntohar, Jembatan. Yogyakarta: Beta Offset, 2007.

[2] F. Sukmana and H. Vaza, "Jembatan Indonesia: Sekarang dan Mendatang," Jakarta, 2016.

[3] L. Susanti et al., "Rangka Canai Dingin Terhadap
Lendutan,” vol. 10, no. 3, pp. 205-210, 2016.

[4] A. N. Refani, "Studi Alternatif Bentuk Rangka Jembatan Canai Dingin Untuk Pejalan Kaki Bentang Kecil Terhadap Rasio Berat dan Lendutan," J. Apl. Tek. Sipil, vol. 15, no. 1, p. 25, 2017.

[5] S. N. R. Anwar, "Kinerja Aksial dan Lentur Sambungan Adhesive Pada Struktur Baja Ringan," Institut Teknologi Sepuluh Nopember Surabaya (ITS), 2016.

[6] B. R. Ellis and T. Ji, "Load Generated by Jumping Crowds : Numerical Modelling," Struct. Eng., vol. 81(6), pp. 20-27, 2004.

[7] F. P. Figueiredo, J. G. S. da Silva, L. R. O. de Lima, P. C. G. da S. Vellasco, and S. A. L. de Andrade, "A parametric study of composite footbridges under pedestrian walking loads," Eng. Struct., vol. 30, no. 3, pp. 605-615, Mar. 2008.

[8] SNI 7971-2013 Struktur Baja-Canai Dingin. Jakarta, 2013.

[9] J. Packer, "Symposium of Adhesive Technology, Polymer Gorup of the NZIC," 1990.

[10] Sumaidi, "Perilaku Sambungan Geser Dengan Lem Pada Elemen Tarik Baja Ringan," Institut Teknologi Sepuluh Nopember Surabaya (ITS), 2015.

[11] I. Komara, "Studi Numerik Perilaku Sambungan Baut dan Adhesive Pada Struktur Rangka Atap Baja Ringan," Institut Teknologi Sepuluh Nopember Surabaya (ITS), 2017.

[12] W. A. Santoso, "Studi Eksperimental Sambungan Sekrup dan Adhesive Pada Struktur Atap Baja Ringan Dengan Variasi Tipe Rangka Kuda-Kuda," Institut Teknologi Sepuluh Nopember Surabaya (ITS), 2019. 
